\title{
Challenges and Countermeasures of Higher Education in China Under the Conditions of New Media*
}

\author{
Wei Wang \\ Wuhan Donghu University \\ Wuhan, China 430212
}

\begin{abstract}
Based on digital technology, the new media that takes the network as a carrier for information dissemination is rapidly developing among contemporary higher education in China under the coercion of new technological revolution, which causes higher education in China to face the challenges of educational marginalization, teaching entertainment, and system stigmatization. To solve this problem, colleges and universities in China are required to truly put emphasis on the education center for college students, and concentrate efforts on educational purposes, educational content, educational methods, and educational expressions, so as to build a higher education system in China under the conditions of new media.
\end{abstract}

Keywords-new media; higher education in China; challenges; college students

\section{INTRODUCTION}

Along with the development and popularization of information technology, the new media that is based on digital technology and takes the network as a carrier for information dissemination is rapidly developing among contemporary higher education in China, which directly leads to fragmentation and entertainment of information acceptance of college students. Under the new media, the contradiction between the learning demands of pursuing for fresh and showing oneself and systematic and rigorous higher education system in China has become one of severe challenges of higher education in China. To this end, how to cope with challenges and explore countermeasures has become a major topic in higher education in China.

\section{The ARrival of NeW Media ERA}

At present, a major change in the field of information spreading is the new media, which is rapidly developed by the combination of network terminals represented by mobile phones and information terminals represented by WeChat, is flourishing. In May 2018, a quarterly financial report released by Tencent showed that WeChat users exceeded 1 billion for the first time, reaching 1.04 billion. The 2017 China Banking Service Report showed that the amount of bank transactions of China' mobile phone reached 96.929 billion. According to the study by relevant institutions in the UK, Tencent and Alibaba

*Research on New Media Approaches of Socialist Ecological Civilization Education with Chinese Characteristics of Youth Fund Funding Project of Wuhan Donghu University, No: 2017dhsk008. have entered the top ten of the world's most valuable brands. It can be seen from the above data that the rise of new media has undoubtedly become one of the most important features of our era. "The medium is the message." 33 Mobile phones and the new media that takes cell phones as a carrier are changing Chinese people's information acceptance and expression, and then unconsciously changing and influencing Chinese people's real life and ideological appeals. Today, the new media is not merely the main form of information spreading among college students in colleges and universities in China. Because of the new media's own characteristics, the content and structure of the information also increasingly highlight the thinking characteristics of contemporary college students and show a strong personal style in the process of information spreading. Therefore, American magazine, Wired, has defined new media as "the spread of everyone to everyone".

With the rise of new media, the education system in higher education in China, which takes video, language and characters as the representative means of teaching, is facing a practical dilemma that is constantly weakened. What is noteworthy is that information dissemination media not only reflects the external form of information, but also determines its inner spirit. In the traditional media era, the inner spirit of transmission is often a rigorous and logical speculation in the communication system with language and characters as the central symbol. Therefore, the external form of traditional media often reflects a systematic and accurate expression. In the new media era, the inner spirit of the transmission in the cultural form that takes visual image as central symbol in communication is the desire to seek new change and innovation and express oneself, which directly causes that the external form of the new media often manifests the remarkable personality and self-venting. With the transformation of traditional media to new media, the external manifestation and core connotation of information spreading have also changed. The spiritual core of truth seeking and dream pursuing in traditional media is declining, and the recreational spirit of innovation seeking and self-expression in new media is growing. One of the most intuitive manifestations of this phenomenon is the daily rankings of WeChat's hot search. Entertainment news or recreational political, religious, sports, educational and business information has always firmly occupied the core position of this new media platform that affects more than one billion users. Pan-entertainment is increasingly becoming the most vivid sketch of the new media era. 


\section{Challenges That Higher EdUCATION IN China FACES UNDER NEW MEDIA CONDITIONS}

The ultimate goal of higher education in China is to "strengthen moral education and cultivate people", (2). The cultivation of talents in higher education in China not only focuses on the teaching of professional skills, but also on the shaping of the noble personality and character of college students. There is a great difference between the spiritual core and value orientation of the new media and the goal of higher education in China, which makes higher education in China face a series of new challenges.

\section{A. Teaching Links Face the Challenge of Marginalization}

The teaching effect is the most important basis for evaluating and measuring the level of higher education. Colleges and universities in China attach great importance to teaching problems, and always regard the improvement of teaching quality and teaching effect as the core issues in the reform of education and teaching in colleges and universities. However, the teaching links are facing the challenge of marginalization in the new media era. The most typical external manifestation is that the university class in China is increasingly facing the impact of mobile phones. To cope with this problem, many colleges and universities in the teaching management have turned the improvement of "class attendance" into the current enhancement of "class head-up rate". The reason is that in many universities' class, students are often absent-minded, concentrate on playing cell phone and have no time to pay attention to the class teaching, and this kind of phenomenon has become common. The emergence of class phubber is related to the problems of some teachers in teaching content and teaching methods. However, the reason why it can't be ignored is the influence of new media on the means of acquiring knowledge of college students. In the traditional media era, the places and occasions where college students seek knowledge are classrooms, libraries, and electronic reading rooms. Through learning in class and thinking after class, college students can enhance their confidence and understand life in the growth of knowledge. Only a short while ago, those experts and professors who were knowledgeable, and preached and taught were the learning goals and life idols of college students in China. In such an atmosphere, the classroom is in the center of higher education in China because it fits the realistic and spiritual demands of college students naturally. However, intelligent big data analysis and calculation can spread highly targeted fragmented information to college students' mobile phones in the era of new media. This kind of method of information spreading has satisfied the knowledge demands of college students' seeking change and innovation and self-expression, so that more and more college students are satisfied with the so-called wanting in care "Encyclopedia" which is provided by network in the acquisition of knowledge. The authority of the classroom and teachers has been greatly challenged, and the idols that young people worship today often become entertainment stars with distinct personality and outstanding image. In such an atmosphere, the rigorous and systematic higher education system is increasingly unable to meet the knowledge needs of college students, which directly leads to the marginalized time challenges of class teaching in the process of youth growth.

\section{B. Education Connotation Faces the Challenge of Entertainment}

Higher education is a professional education based on the completion of secondary education. It is a main social activity for cultivating high-level professionals and a strict and systematic education system. However, under the conditions of new media, college teachers and education administrators in China, in the combined action of various factors, are increasingly inclined to teach and manage in the education practice in an entertaining way, so that the connotation of higher education in China faces the challenge of being entertained. In recent years, the overall teaching quality and teaching level of higher education in China have been continuously improved through the efforts of all parties, and remarkable achievements have been made in education. However, it should also be noted that the phenomenon of teaching connotation entertainment has emerged from time to time in higher education in China, especially undergraduate teaching. For example, in many classrooms, individual teachers will talk about some anecdotes of classic writers and classic works in a quip to improve the atmosphere of teaching and attract students' attention. To improve students' enthusiasm for participation, individual teachers organize students to carry out academic seminars, and cater for students without principle instead of conquering students with authoritative views and rigorous arguments, and their academic position is swinging. Even some teachers has given amazing lecture to obtain the so-called "applause" from the students. The practice of teaching connotation entertainment of these teachers has weakened the authority of the connotation of higher education and has had a certain negative impact on higher education in China. Moreover, there are occasional entertainment phenomena in the daily management of Chinese universities. For example, in some colleges and universities, when organizing students activities in colleges and universities, the first thing that comes to some student staff's mind is not the rigorous activities including academic lectures, reading parties and debates, but to increase the so-called "popularity" of the activities and to arrange for more entertaining "songs and dances" for catering to some students' demands. In general, the challenge of entertainment in higher education in China is, to a large extent, a helpless and unconscious choice made by college teachers and college administrators under the conditions of new media, and of contemporary college students' seeking changes and innovation and self-expression, and in the long-term teaching and management practice.

\section{Education System Faces the Challenge of Stigmatization}

Teachers are the successors and communicators of human cultural science knowledge. In China, teachers have always been respected by people and are courteously called "engineers of the human soul". However, under the conditions of new media, the image of university teachers and higher education in China is often destroyed and faces the challenge of being stigmatized. This phenomenon is highlighted in two aspects. First of all, the professional image of higher education workers in China is deteriorating. Today, when the workers of higher education are reported every time due to various problems, it is followed by questions and hype on the new media platform. The individual problems are infinitely magnified, even the 
stigma is imposed on the whole group of higher education workers. Therefore, "specialist", "profartssor" and other negative vocabulary of new media emerge in endlessly. Second, the image of higher education in China also faces being damaged. For instance, in many places, the sentence that "reading changes life" has been questioned because of the short-term gains and losses of individuals, however, the idea of "the uselessness of study" becomes popular. The root of these phenomena lies in the fact that in the traditional media era, because the higher education, the social functions and professional orientation of college teachers are better suited to the demands of traditional media, their social roles can be positively strengthened in communication and thus gain good social recognition. Higher education in China and university teachers also has won a glorious positive image. However, under the conditions of new media, in the cultural context of seeking change and innovation and showing oneself, the social role played by higher education is incompatible with the cultural demands of college students, and its social role is negatively strengthened during information dissemination. The phenomenon has caused that higher education and university teachers face the challenge of being stigmatized.

\section{THE COUNTERMEASURES FOR THE DEVELOPMENT OF HIGHER EDUCATION IN CHINA UNDER THE CONDITIONS OF NEW MEDIA}

"People's social history is always just a history of their individual development, whether they realize it or not." ${ }^{\text {,3 }}$ P532 In this sense, the external form that new media may show in different people's eyes varies widely, but in essence it points to the real world and reflects the real needs of people. Therefore, in order to effectively solve the series of challenges faced by higher education in Chain under the conditions of new media, college administrators and college teachers take the real demands of contemporary college students as the core in the reform of education and teaching, so as to guide higher education in China to return to reality.

\section{A. Achieving the Combination of Social Needs and Personal Development in the Educational Goal}

Tracing the source, the current higher education in China derives from the imitation and learning for Soviet education system in planned economy times. In education, we often emphasize first that the goal of higher education is to meet the needs of the society, but do not attach enough importance to the needs of educational object, that is, college students. We should see that the objective concept of higher education in China under this mode has adapted to the real needs of the society for talents at that time, and made an important contribution to the development of revolution, construction and reform causes. However, it is more difficult for this kind of educational goal to meet the personal development needs of college students under the conditions of mew media. To strengthen and consolidate universities' main channel status in the growth and development of students, we should firmly establish the "student-centered" concept and take the goal that meets students' growth and development and expectation as the center in the reform of education and teaching. In terms of educational goals, we should change the idea that simply emphasizes social needs to the concept that pays equal attention to social needs and individual needs.

\section{B. Combining Theory with Practice in the Teaching Content}

We emphasize the basic and dominant position of teaching materials in educational content in the current practice of higher education in China. Due to the objective requirements of teaching materials compilation, higher education presents obvious characteristics of rationality and abstraction. This knowledge system, which is divorced from the life and practice of college students, inevitably affects the spreading of teaching content and the realization of teaching objectives. Some college students are not interested in the contents of lectures and teaching materials, and their enthusiasm for learning is not strong, which is the true reflection of this phenomenon. Therefore, college teachers should pay attention to organically combining the knowledge system that teaching conveys with the life practice of college students. In the process of education, teachers should consciously use the people and things around to explain the abstract and theoretical knowledge. For example, when the "modern and contemporary Chinese history" education is conducted, if only based on the teaching materials, college students often only accept some boring data and messy events, and the educational goals cannot be truly realized. However, the educational effect will be qualitatively improved in combination with the examples in our life. For example, when introducing the Revolution of 1911, we can combine the historical coordinates Wuhan, the first uprising city. Combining with historical events, figures, buildings, relics and comparison of future and past, we carry out heuristic teaching, debating teaching and practical teaching, turn theoretical system into vivid life practice, and enable students to change from passive infusion to active learning, so as to realize the combination of theoretical and practical content in higher education.

\section{Combining Cramming Teaching and Heuristic Teaching on Educational Methods}

The theoretical cramming is still the main method of education and teaching in the current practice of higher education in China. Several decades' practice of higher education in China shows a certain range and a certain degree of theoretical cramming are necessary and effective. However, with the development of higher education in China, the theoretical cramming method has also shown some defects. In the education and teaching, individual teachers always emphasize the rote learning and make students know why but do not know why, which obviously violates the original intention and mission of higher education's cultivating senior talents. The famous "Asking of the Qian Xuesen" is the embodiment of this phenomenon. In recent years, with the development and promotion of a series of teaching innovation represented by "flipped classroom" in the new media age, its mechanism has revealed that the methods and ways for college students to acquire knowledge are diverse. Teachers can fully combine the knowledge characteristics of this subject and this course, make full use of huge information resource of the new media, and fully guide students to play the initiative of autonomous learning, so as to achieve the combination of 
cramming teaching and autonomic learning in teaching methods.

\section{COMBINING TECHNICALITY WITH CONTEMPORANEITY IN EDUCATIONAL DISCOURSE}

The academic discourse system widely used to highlight the authority of teaching content is the mainstream style of higher education discourse in the current practice of higher education in China. The standard and rigorous expression of academic discourse can show the teaching content systematically and comprehensively, so the use of academic discourse in higher education practice is necessary. However, this kind of academic discourse also has some defects. The most prominent is that college students' knowledge demands of seeking change and innovation in their thinking are completely matched under the conditions of new media. Most of the time, when teachers organize teaching interactions, professional and rigorous academic questions often fall into a situation that questions are too difficult to understand and no one responds. Therefore, in the process of education, teachers should be good at expressing the education content in language and words that are close to the daily life of college students. The teacher must learn to give students" "gelivable" leaning performance "thumbs up'. Such educational discourses are more likely to resonate emotionally with educational objects, and educational content is more easily understood and accepted by educational objects, thus achieving a combination of technicality and contemporaneity.

\section{CONCLUSION}

At present, China is in a crucial historical node to realize the great rejuvenation of the Chinese nation, and the role and significance of higher education in China are increasingly prominent. People's need for higher education is more urgent than ever before, and China's thirst for scientific knowledge and talent is stronger than ever before. Higher education administrator and the vast university teachers must clearly understand their responsibilities and missions. They must closely follow the background of the high development of the new media era, be closely around the educational object of college students, carry out teaching research and innovation around educational goals, educational content, educational methods and educational expressions, and build the higher education system in China under the conditions of new media, so that higher education in China can truly meet the expectations of the country and the people.

\section{REFERENCES}

[1] [Canada] Marshall Mcluhan. Understanding Media:The Extensions of Man [M]. Translated by He Daokuan. Beijing: The Commercial Press, 2007. [加]马歇尔 - 麦克卢汉. 理解媒介: 论人的延伸[M]. 何道宽, 译. 北京:商务印书馆，2007.

[2] Xi Jinping. Secure a Decisive Victory in Building a Moderately Prosperous Society in All Respects and Strive for the Great Success of Socialism with Chinese Characteristics for a New Era - Report at the 19th National Congress of the Communist Party of China [N] People's Daily, 2017-10-27 (1). 习近平.决胜全面建成小康社会 夺取新时代中 国特色社会主义伟大胜利一一在中国共产党第十九次全国代表大会 上的报告[N]人民日报，2017-10-27（1）。
[3] The Collected Works of Marx and Engels, Volume 4 [M]. Beijing: People's Publishing House, 1995. 马克思恩格斯选集，第 4 卷 $[\mathrm{M}]$. 北 京: 人民出版社, 1995 . 